Advanced Research in
$\frac{\text { Gastroenterology \& Hepatology }}{\text { ISSN: 2472-6400 }}$
$\begin{aligned} & \text { Oolume 12 Issue 2- January } 2019 \\ & \text { DoI: 10.19080/ARGH.2019.12.555832 }\end{aligned}$
Copyright (C) All rights are reserved by Mohamed Mansour El-Loly

\title{
Immune Defenses of Colostrum and Milk in Human and Animals
}

\author{
Mohamed Mansour El-Loly* \\ Dairy Science Department, National Research Centre, Egypt \\ Submission: November 28, 2018; Published: January 25, 2019 \\ "Corresponding author: Mohamed Mansour El-Loly, Dairy Science Department, National Research Centre, 33 El-Buhouth St. Dokki, P0 12622, Giza, \\ Egypt
}

Keywords: Colostrum; Milk; Immunoglobulins; Antibodies; Immune defense; Immunology; Mammary gland; Bactericidal property; Chew; Digest solid food

\section{Opinion}

The concept that milk, mammary secretions and the mammary gland have significant roles in immune defense is an old one. The bactericidal property of milk was recorded in the late nineteenth century. Also, observations at this time on the ability of milk to provide immunity to the newborn assumed a key role in the development of modern immunology. The mammalian neonate can't to collect, chew, or digest solid food, depending completely on the colostrum of its mother and subsequently on milk for its survival. In addition to providing a complete diet with all the essential nutrients for the neonate through the initial period of its life, colostrum also gives basic immunological protection against surrounding pathogens. In ruminants specifically, for which no exchange of immune factors happens in uteri, colostrum and milk provide protection through high immunoglobulins (Igs) or antibodies content, without which the ruminant would not, survive Larson et al. [1].

The Igs of colostrum, in conjunction with the ability of the ruminant neonatal gut to allow unrestricted passage of the large Ig molecules, provide the young animal with passive immunization. However, both the Igs levels in colostrum and the permeability of the gut decrease quickly and continuously over the initial $48 \mathrm{~h}$ after birth. Bush \& Staley [2] \& Moore et al.[3]. Until the immune system of the offspring is developed, immunoglobulin level in the blood continues to increase for a certain period and increasing colostrum increases the viability of the offspring, Alves et al. [4]. Therefore, an adequate supply of colostrum, with abundant Igs, is essential during this brief period of time for the young to gain sufficient passive immunity to be able to survive until its own immune system is completely developed.

The immunological memory of the mother, as Igs, is transported from mother to the offspring through two main pathways: the first, in uteri, in which maternal Igs passes through the placenta into the circulation of the developing fetus, and the second via colostrum, in which Igs are first secreted into the colostrum in the mammary gland as well as, after ingestion by the suckling newborn, is taken up into the gastrointestinal tract (GI). Mammals can be roughly divided into three groups according to their Igs transfer pathways. Humans and rabbits have placental transfer; the serum Ig levels of newborn humans equal those of their mothers. Ruminants and some common domesticated animals, like cows, horses, pigs, sheep and goats, don't use the in uteri pathway but gain Igs through extensive colostrum transport. Such animals are born virtually without antibodies, and thus their immune system depends on the ingested maternal colostrum.

High colostral Igs levels, mainly IgG, are characteristic to species that receive maternal Igs through colostrum. The newborn ruminant's gut permits unselective transfer of Igs and other macromolecules into circulation only during the first 12-36 $\mathrm{h}$ after birth. In pigs and horses (but not in cows) the transition of colostrum to mature milk is associated with a conversion of the major Ig class from IgG to dimeric secretory immunoglobulin A (sIgA). Some animals, like cats, dogs and rats can utilize both Igs transfer pathways; in dogs and rats, IgG is the major component of colostrum, and IgA is a minor component. The principle physiological function of lacteal SIgA seems to be to passively protect the GI by binding to pathogens and preventing them from attaching to mucosal epithelial cells. The IgG role in mature milk of extensive placental Ig transporters might be principally to protect the mammary gland, Lilius \& Marnila [5]. Additionally, immune factors in colostrum and milk play a vital role in the host defense of the mammary gland itself, protecting it from pathogenic organisms. The mammary gland is very susceptible to infection due to mammary secretions give an excellent source of nutrients for pathogens, the body temperature is ideal for 
bacteria growth, and the gland via the teat opening has a direct link to the external environment. The mammary host defense system has advanced into an extremely well-developed, complex and highly effective barrier against pathogens, incorporating both the innate and acquired immune response, Sordillo et al. [6] \& Oviedo-Boyso et al. [7].

Colostrum and milk give a complete diet for the neonate. Also, in ruminants it is the single source of initially acquired immunity for the offspring. Consequently, it assumes a vital role in mammalian host defense. In colostrum, the Igs level is particularly high, with predominant IgG of Igs molecules in ruminant milk, but as opposed in human milk that IgA being a major Ig class. Igs are transported into mammary secretions via specialized receptors. Furthermore, both colostrum and milk Igs contain viable cells, including neutrophils and macrophages that secrete a range of immune-related components into milk. These include cytokines as well as antimicrobial proteins and peptides, like lactoferrin and cathelicidins, Stelwagen et al. [8].

Colostrum feeding time and amount through the first 72 hours are critical in the transfer of passive immune substances to ruminant farm animals, like cattle, sheep and goat, as well as in the resultant viability of the offspring. This is due to the hypogammaglobulinemia of the offspring. Colostrum intake is a great importance in the viability and passive immunity development in newborn animals, Stelwagen et al. [8] \& Hernandez et al. [9], [10]. Consequently, particularly artificially reared animals must get a sufficient of colostrum, Morales et al. [11], [12]. Colostrum composition varies markedly from milk, reflecting a variance in the biological function of the two secretions. Additionally, the physical and physicochemical properties of colostrum are substantially different from those of mature milk, and given increasing interest in colostrum either as a healthpromoting product or a source of fractions with such properties, these properties are of considerable interest, McGrath et al. [13]. Goat colostrum secreted in the postpartum period, it is essential for the immune substances to be taken as soon as possible since the rate of passage of the immune substances transferred through the intestinal epithelium by this way decreases in time, Kosum et al. [14].

\section{References}

1. Larson BL, Heary JrHL, Devery JE (1980) Immunoglobulin production and transport by the mammary gland. J Dairy Sci 63(4): 665-671.

2. Bush LJ, Staley TE (1980) Absorption of colostral immunoglobulins in newborn calves. J Dairy Sci 63(4): 672-680.

3. Moore M, Tyler JW, Chigerwe M, Dawes ME, Middleton JR (2005) Effect of delayed colostrum collection on colostral IgG concentration in dairy cows. J Am Vet Med Assoc 226(8): 1375-1377.

4. Alves AC, Alves NG, Ascari IJ, Junqueira FB, Coutinho AS, et al. (2015) Colostrum composition of Santa Ines sheep and passive transfer of immunity to lambs. J Dairy Sci 68(6): 3706-3716.

5. Lilius EM, Marnila P (2001) The role of colostral antibodies in prevention of microbial infections. Curr Opin Infect Dis 14(3): 295-300.

6. Sordillo LM, Shafer-Weaver K, DeRosa D (1997) Immunobiology of the mammary gland. J Dairy Sci 80(8): 1851-1865.

7. Oviedo-Boyso J, Valdes-Alarcon JJ, Cajero-Juarez M, Ochoa-Zarzosa A, Lopez-Meza JE, et al. (2007) Innate immune response of bovine mammary gland to pathogenic bacteria responsible for mastitis. J Infect 54(4): 399-409.

8. Stelwagen K, Carpenter E, Haigh B, Hodgkinson A, Wheeler TT (2009) Immune components of bovine colostrum and milk. J Anim Sci 87(13): 3-9.

9. Hernandez-Castellano LE, Almeida AM, Castro N, Arguello A (2014) The colostrum proteome, ruminant nutrition and immunity. Curr Protein Pept Sci 15(1): 64-74.

10. Hernandez-Castellano LE, Almeida AM, Ventosa M, Coelho, AV, Castro N, et al. (2014) The effect of colostrum intake on blood plasma proteome profile in newborn lambs: Low abundance proteins. BMC Vet Res 10: 85.

11. Morales-delaNuez A, Moreno-Indias I, Sanchez-Macias D, Capote J, Juste MC, et al. (2011) Sodium dodecyl sulphate reduces bacterial contamination in goat colostrum without negative effects on immune passive transfer in goat kids. J Dairy Sci 94(1): 410-415.

12. Morales-delaNuez A, Moreno-Indias I, Sanchez-Macias D, HernandezCastellano LE, Suarez-Trujillo A (2014) Effects of Crypthecodinium cohnii, Chlorela spp and Isochrysis galbana addition to milk replacer on goat kids and lambs growth. J Appl Anim Res 42: 213-216.

13. McGrath BA, Fox PF, McSweeney PLH, Kelly AL (2016) Composition and properties of bovine colostrum: a review. Dairy Sci \& Technol 96: 133158.

14. Kosum N, Taskın T, Kınık O, Kandemir C, Akan E (2018) A study on the change in postpartum immunoglobulins of goats and kids. J Anim Prod 59(1): 1-8.

\section{Your next submission with JuniperPublishers will reach you the below assets}

- Quality Editorial service

- Swift Peer Review

- Reprints availability

- E-prints Service

- Manuscript Podcast for convenient understanding

- Global attainment for your research

- Manuscript accessibility in different formats

( Pdf, E-pub, Full Text, audio)

- Unceasing customer service

Track the below URL for one-step submission https://juniperpublishers.com/online-submission.php 